\title{
RESEARCHARTICLE
}

\section{Women's marital liberty and the missing negative right in article 23 of ICCPR}

\author{
Ya'arit Bokek-Cohen
}

Department of Family Studies, The Academic College of Management Studies MOFET Institute, Israel

\begin{abstract}
The article calls international attention to the need to augment the right to marry, which is the focus of Article 23 of ICCPR. While the current content of Article 23 refers only to the positive right to marry, it fails to acknowledge an important negative right regarding marriage. Specifically, there are many cases divorced women who are proscribed from marrying their partners. As a case study, I use the forbidden marriage of a divorced woman and a Cohen (a descendant of Jewish Priests) in Israel. In order to illustrate the plight experienced by women who wish to marry their beloved spouses and are restricted by law, I provide an auto-ethnography and share my own experience as a formerly divorcée who was not allowed to marry a Cohen. I conclude with sociological and philosophical insights into marital transgressions and offer suggestions for future advancement of women's marital and familial human rights.
\end{abstract}

\section{Keywords}

Auto-ethnography; divorced women; ICCPR; marital liberty; marital prohibitions

There is an ever-growing number of scholars interested in the relationship between religion Open Access and human rights. Nussbaum (2000) argues that the abridgement of certain human rights owing to religious traditions entails more severe consequences in states where religions and legal systems are intertwined. I demonstrate Nussbaum's (2000) claim in the Israeli context, where personal law is almost solely determined by religious judicial authorities, owing to the political agreement of "status quo".I showcase Nussbaum's observation that, "'an organic good for the group is unacceptable if it does not do good for the members taken one by one" (Nussbaum, 2000, p. 188), in the realm of women's marital liberty.

The article calls international attention to the need to augment the right to marry, which is the focus of Article 23 of the International Covenant on Civil and Political Rights 1966 (ICCPR) (to be referred henceforth as "Article 23" in this brief). While the current content of Article 23 refers only to the positive right to marry, establish a family and freely choose one's marital partner, it nevertheless fails to acknowledge an important negative right with regard to establishing a family, i.e. not to be proscribed from marrying a specific spouse or a member of a specific social category. Specifically, there are many cases around the globe in which women are forbidden to get married with certain categories of men, despite alleged free will in marital choices and decisions. The present essay aims at exposing this travesty of human rights thus increasing international awareness, as a necessary though insufficient step toward remedying such violations in societies worldwide. I discuss the necessary amendment of Article 23 to include explicitly stated guidelines to avoid the infringement of the right to establish a marital union of a man and a woman of marriageable age who are mutually prohibited from marrying each other. As a case study, I use the forbidden marriage of a divorced woman and a Cohen (a descendant of Jewish Priests) in Israel, from which we can learn about this kind of human right violation and its attendant predicament. In so doing, I focus "....on an ethnographic perspective that privileges individual, situated experiences in practice 
over discourses and community representations" (Koensler, 2018, p. 3).

The article is constructed as follows: I begin with an overview of some examples of women's forbidden marital unions in various states and cultures around the world; I proceed to describe the legal background of the marriage law in Israel and overview the various cases where women are forbidden to get married with certain men of specific characteristics. In order to illustrate the predicament experienced by women who wish to marry their partners and are restricted by law, I share my own experience as a formerly divorcée who was not allowed to marry a Cohen. In order to let the reader enter our inner world, I dedicated an autoethnographic section describing in detail potential sources of pain and distress for my husband and me as a couple who married, despite the religious prohibition. I conclude with sociological and philosophical insights into marital transgressions and offer suggestions for future advancement of women's marital and familial human rights.

\section{Introduction}

The International Covenant on Civil and Political Rights (ICCPR) guarantees that the right to marry will be equally recognized for both women and men in Article 23 as follows: 1). The family is the natural and fundamental group unit of society and is entitled to protection by society and the State. 2). The right of men and women of marriageable age to marry and to found a family shall be recognized. 3). No marriage shall be entered into without the free and full consent of the intending spouses. 4). States Parties to the present Covenant shall take appropriate steps to ensure equality of rights and responsibilities of spouses as to marriage, during marriage and at its dissolution. In the case of dissolution, provision shall be made for the necessary protection of any children. Similarly, article 12 of the European Convention on Human Rights (EUHR) provides a right for women and men of marriageable age to marry and establish a family: "Men and women of marriageable age have the right to marry and to found a family, according to the national laws governing the exercise of this right". The right contained in Article 12 is closely related to Article 8 of the EUHR, which secures a right to respect for one's "private and family life, his home and his correspondence."Article 16 (1) of the Universal Declaration of Human Rights (UDHR) contains a similar provision: "Men and women of full age, without any limitation due to race, nationality or religion, have the right to marry and to found a family. "Israel ratified the ICCPR, and also has observer status in the EUHR (as do additional non-European democratic states) who wish to adhere to human rights in Europe. The protection of marital liberty is limited to heterosexual marriage and is not applied de facto to same-sex marriages.

The right to marry and establish a family constitutes a human right (Eekelaar, 2011; FogielBijaoui, 2002, 2017; Merin, 2005), because anyone can claim this right without fulfilling any prerequisites besides being human (Eekelaar, 2011). However, over the past years, we have witnessed the inability of governments to prevent the violation of marital and familial human rights, and state law remains silent when bypassed by various religious and/or traditional marriage practices. For example: Muslim religious marital law permits polygamous marriages and discriminates against women with regard to their rights in divorce and dissolution of marriage (Rehman 2007); some countries have banned polygamous Muslim marriage (Douki, Ben Zineb, Nacef, \& Halbreich, 2007; Van Wichelen, 2009), a relatively recent prohibition which bears the potential to lessen human rights infringement of Muslim women. Mexico cannot always prevent women from being married off against their will (Frías, 2017). The present article joins extant scholarship on human rights violation and exposes the plight of women who transgress ancient religious prohibitions which stem from a violation of their human rights in the democratic state of Israel. In order to better understand the sources for this violation, the Israeli personal law system is described hereafter.

\section{The personal law system in Israel}

Israel inherited the Millet personal law system from the Ottoman Empire and the subsequent British mandate (Ahmed, 2016; Galanter \& Krishnan, 2000; Sezgin, 2013). In a Millet system, each religious group has religious autonomy at the community level, and the sovereign government recognizes the prominent religious leadership which is granted the authority to conduct family matters such as marriage, divorce, alimony, and succession. This system does not acknowledge the possibility that members of a certain religious group do not self-identify with their "formal" religious affiliation (Ahmed, 2016), and consequently, atheists or secular individuals may experience religious coercion (Cohn, 2002; Fogiel-Bijaoui, 2003). Israeli 
leaders preserved and reinforced the Millet system in order to increase the homogenization among Jews and enlarge the segregation between Jews and non-Jews (Fogiel-Bijaoui, 2003; Sezgin, 2013). The theocratic nature of the state of Israel as well as its Judeocentric focus paved the way to the formation of what Sezgin (2013, pp. 37-38) calls the "fragmented confessional" model of personal status system, i.e., a system where each ethno-religious sector has its own court, in which it applies its religious laws and norms through the state's legal institutions.

Since a state's ability to intervene in personal status issues depends upon its relative power vis a vis that of other social parties (Sezgin, 2013; Eekelaar, 2017), the religious family law system has been enforced by the state because of the large political power of the Orthodox parties in the Israeli parliament, as compared to that of the secular parties. This enforcement dates back to 1948 when Israel achieved independence; while the religious parties wished to form a kind of theocracy, the secular parties pushed for a secular civic state that respects religious freedom (Galanter \& Krishnan, 2000). The government was torn between the two opposing directions, and eventually settled for an arrangement known as the "status quo" agreement. According to this arrangement, the government pledged to continue recognizing the religious authority and to follow patterns of publicly enforced religious observance as were followed before gaining independence.

Currently, questions and matters of marriage and divorce are exclusively determined by religious judicial institutions, while other family issues are determined by both religious and civil state judicial institutions, depending on the court to which the suit was initially submitted (Galanter \& Krishnan, 2000; Scolnicov, 2006). There is neither civil marriage nor civil divorce in Israel (Fogiel-Bijaoui, 2002; Sezgin, 2013), and couples who wish to marry in a civil marriage go abroad for this purpose; their marriage is acknowledged by the state, thanks to international laws (Ben-Porat \& Feniger, 2012; Fogiel-Bijaoui, 2002), though not every couple can afford the expense of a civil marriage service in another country.

\section{Some examples of forbidden marriages around the globe}

Following is a literature review of marriage prohibitions in various cultures and religions around the world. When browsing the electronic databases of scientific publications, I entered the following search terms: "forbidden marriage"; "proscribed marriage"; "prohibited marriage"; and also "marital prohibitions" and "marital liberty". My search found numerous books and articles focusing on same-sex marriage or interfaith and inter-ethnic conjugal liaisons. I do not include here prohibitions against incestuous, interfaith, inter-ethnic or interracial marriages, nor same-sex or marriages of partners younger than marriageable age. I found only a few articles which deal with cases similar to Cohen-divorcée Couples (CDC henceforth), i.e. forbidden heterosexual marriage for divorced women and male partners belonging to the same race, religion and nationality.

I believe that there are additional cases of women's forbidden marriages that have not been previously studied. A reasonable potential reason for the under-representation of this topic in academic scholarship is the fact that women in forbidden marriages are methodologically hard to reach, as they are a "hidden population" which usually prefers not to be identified nor approached by researchers. As a social scientist who is committed to enhancing human well being and justice, I therefore wish to speak, or better to shout out, in the name of all of the silenced members of forbidden conjugality worldwide, and promote a real change in Article 23, which is assumed to be implemented in all the states that ratified the ICCPR.

What is common to all of the following examples is that at least one of the two prospective marital partners has something to lose if $s$ /he marries a specific member of another social category within their religion and people (Ermakoff, 1997). Transgression of traditional, cultural or religious practices entails various sorts of social sanctions placed on one or both partners. For example, Exogamous matrimonial liaisons of aristocrats and prelates were discouraged because they threatened the continuity of family property ownership in England (Ermakoff, 1997), and the same is true with regard to intermarriage between Bedouins of different tribes in the southern area of Israel (Abu-Rabia-Queder, 2007).

Perhaps the most well-known marital prohibitions are those of Indian inter-caste conjugality. In India, individuals are born into a caste; the hierarchical caste system reproduces itself via marriage within each caste. Despite increasing interest in exogamous marriage, caste plays a significant role and caste-based hierarchy is still perpetuated in modern Indian society (Ahuja 
\& Ostermann, 2016; Chatterjee, 2010). Kapila (2004) studied the Gaddis, a pastoral people living in the Kangra region of Northern India; although love marriages amongst the Gaddis were recognized by law, love marriages for the Gaddis usually relate to a case where the two spouses had married outside their caste, and this marriage was socially sanctioned. PeledShapira (2013) called attention to traditional Iraqi matrimonial prohibitions in which a woman cannot marry before her older sisters. In Guinea, artisan groups are reputed to marry only endogamously, a norm that has led some anthropologists to refer to them as castes. Interstatus marriages between "lower status" men and "higher status" women are scarce; such a union raises the man's status and prestige (Furth, 2005). In Muslim law, a man and a woman who were breast-fed by the same woman are mutually proscribed from marrying each other, following the concept of 'milk kinship' (Clarke, 2007). In Catholic law, marriage between second cousins was allowed only in 1969, and marriage between first cousins is not accepted (Ottenheimer, 1996). Also, the Church of England did not then allow divorced people to remarry in church if their ex-spouses were still alive, therefore King-Emperor Edward VIII abdicated in order to marry a divorcée. In the $19^{\text {th }}$ century USA, there prevailed a law, albeit controversial, forbidding a man from marrying his deceased wife's sister (Anxious Observer, 1869), and similarly a woman was forbidden to marry her deceased husband's brother; marriage between cousins was also prohibited in the USA, but allowed in England (Anxious Observer, 1869).

\section{The ten pedigrees in Jewish Halakhic marriage law}

The Ten Pedigrees relate to a classification of individuals into a socio-political inner hierarchy within the Jewish community that lived in the land of Israel in Biblical times (Kidushin tractate ch. 4, Mishna A). These Jews were allowed to return to the Holy Land in 538 BCE, a few decades after the destruction of the First Temple, and following Cyrus the Great's declaration that allowed them to build the Second Temple. The Ten Pedigrees were aimed at classifying Jews into categories of marital eligibility; although they were delineated some 2500 years ago, most of the marital prohibitions are still valid and applicable today. Cohanim (the plural form of Cohen, i.e. Jewish priest) belong to the most honorable class and are allowed to marry only into one of the three upper classes, as follows:

1) Cohen (Adescendant of priests who had served at the HolyTemple in Jerusalem)

2) Levy (A descendant of the Tribe of Levy, from which the Cohanim are originated and selected for the service at the Holy Temple)

3) Israel(All Jews who are not descendants of Cohanim or Levy)

4) Chalal ( An offspring born to a Cohen and a woman disqualified from marrying a Cohen; also any offspring of a male chalal for eternity; also a woman who is disqualified from marrying a Cohen whon ever theless had sexual intercourse with him despite the prohibition )

5) $\operatorname{Ger}$ (Aconvert)

6) Haruri( Areleased slave)

7) Giv'oni (A non-Jew who belongs to the people of Giv'on, a people which assimilated into the Jewish people)

8) Mamzer (A child born to a married woman whose biological father is not the legal husband of this woman)

9) Sh'tuki (Achild whose biological father's identity is unknown)

10) Waif (Assufi: An adopted orphan whose genealogical origin is unknown)

Cohanim are not allowed to marry divorcées because they are perceived as possessing a lower "market value" because they lost their virginity in previous marriage and hence are considered as "impure", or not "pure enough" to the highly valued Cohanim, who are treated in some segments of contemporary Jewish society as closest to God, although there is no temple in Israel any more. Cohanim are and also woman who has had certain forbidden sexual relationships; such a woman is called a zonah in the Torah (Lev. 21:7). They are also forbidden to marry a widow whose brother-in-law refused to marry by levirate marriage. The most frequent Jewish family name in Israel is 'Cohen', and today there are 180,000 citizens with this family name. There are several other family names that attest to Priestly descent, such as Katz, Kagan, Kahn, etc., and the number of male Cohanim is estimated to be 260,000. One out 
of every forty Jews is a Cohen. There are 241,700 divorced Jewish women living in Israel: one out of every ten Jewish women over the age of 18 is divorced. Without calculating the ratio by age groups, these women are assumed to participate in a marriage market which is composed of 641,000 never-married women and 199,800 widows. The male part of the Jewish marriage market in Israel is composed of 752,600 never-married, almost 163,000 divorced men and about 47,000 widowers (CBS, 2018). If we estimate the rate of male Cohanim as $1: 40$, we can assume that there are at least 24,000 non-married Cohanim who can meet in romantic circumstances at least one of the 241,700 divorcées. The conclusion is very disturbing: if there are 1,083,000 potential non-married female partners the Cohanim might meet, they are forbidden to marry $24 \%$ of them.

\section{Auto-ethnography of my forbidden marriage}

Before I share my experience of being a formerly divorced women who is involved in a religiously forbidden marriage by offering a short auto-ethnography, it is important to clarify at the beginning, why I believe adding an auto-ethnographic section is useful for raising public awareness of the need to amend Article 23. My explicit objective is touching you, the reader of the present essay, enabling you to "taste" my feelings, which may be unfamiliar to you to date. The reason why I am trying to move you is my strong and sincere sense of vision to diminish women's suffering. As a full-fledged member of the social category of Cohen-divorcée couples, I cannot remain silently on the sidelines; I feel I have a moral obligation to speak in the name of all of the silenced CDCs, as well as other partners involved in forbidden marriages worldwide. Instead of providing "dry" anonymous and distant numbers and statistics of women who could not marry their beloved prospective mates, I believe that one vividly revealing personal story saturated with a dense description of thoughts and emotions can touch the readership, and in doing so, will be much more effective in raising the needed public awareness to amending Article 23.

Ellis and Bochner (2000) who are acknowledged as experts in auto-ethnography, advocate for full disclosure of emotional experience by auto-ethnographers in order to expose a compelling description of subjective emotional experiences, creating an emotional resonance with the reader as the supreme goal of their scientific activity (Ellis \& Bochner, 2000, p. 744). That being said, I preferred to produce here an analytic rather than an evocative autoethnography, which is more suitable to the main goal of the essay. According to Anderson (2006), the term 'analytic auto-ethnography' refers to "research in which the researcher is (1) a full member in the research group or setting, (2) visible as such a member in published texts, and (3) committed to developing theoretical understandings of broader social phenomena" (Anderson, 2006, p. 375).

Secondly, it is noteworthy that I do not represent nor try to represent any CDC, or any other divorced woman who was religiously prohibited to marry her beloved spouse, and all of the experience I share with the readership of this article is based solely on my own subjective perceptions, as well as my interpretation of my husband's and his relatives' narratives. Undoubtedly, there is a great variation in the emotional responses and cognitive interpretation among members of the same social category (Hayano, 1979); Accordingly, each woman of the Cohen-divorcée couple is to be seen as belonging to a social category, and as such, is located in similar socio-legal positions. She may nevertheless have a unique background, distinct familial and social responses to their forbidden love, and different interpretations of their exceptional conjugal status. I am not describing or reporting social facts: I cannot be objective. I invite the readership of this essay to enter a facet of my personal life and evaluate the issue of women's human-right infringement in the story I am telling here. Thanks to my personal involvement and its attendant excitement, some parts of this story were narrated by me during irregular working hours; for example: this paragraph was written at 2 a.m. on a Friday night, and I feel energetic enough to produce a unique documentation of human experience, as if it were 9 a.m. and I was just finishing enjoying a good breakfast and a cup of delicious coffee.

The following auto-ethnography is based on three sources of information: 1) memories I have since our pre-wedding time together, about twenty years to date; 2 ) field notes I took during the last five years since I started this auto-ethnographic project; and 3) recorded and transcribed interviews I started conducting four years ago with my husband, his parents and two brothers.

We met at a party when I was a 29-year-old divorcée with no children and he was a 33-year- 
old never-married man. When we talked on the phone to coordinate a date, I told him I was a divorcée but he did not tell me he was a Cohen (in Israel it is not customary to introduce oneself with one's family name at social events). On our first date, he drove us to a restaurant and entered a one-way street the wrong way. A policeman asked for his driving license and gave him a ticket. This was the first time I realized he was a Cohen, and our entry into a one-way street the wrong way on our first date was amazingly symbolic. I did not say a word about his being a Cohen and we proceeded with our date. After three months, we decided to get married; we knew that the rabbinical court would not approve our marriage, so we had two alternatives for conducting a religious Jewish wedding ceremony, which were the Conservative Rabbinate and the Reform Rabbinate (two alternative religious streams that advocate for a more liberal and modern Jewish law and lifestyle, as compared to the dominant Orthodox stream), neither of which is recognized by the official Orthodox Rabbinate - nor by the Ministry of Interior. My mother-in-law insisted on turning to a Conservative rabbi because they are bearded similar to their Orthodox counterparts. She didn't want her own and her husband's relatives, as she put it, "to suspect that something was irregular here", and eventually, our wedding ceremony was conducted by the chief Conservative rabbi. He told us we could choose an alternative Ketubah (A special type of Jewish prenuptial agreement. It is considered an integral part of a traditional Jewish wedding ceremony, and delineates the rights and responsibilities of the groom toward his bride) which would be more egalitarian with regard to gender roles, but my mother-in-law wanted the standard Orthodox Ketubah, again in order to conceal the fact that the wedding ceremony was not Orthodox. She asked us before the meeting with the rabbi to obey as much as possible all traditional rituals and customs during the planned wedding ceremony: "Don't let me down. I do not wish to be embarrassed there. Promise me you will try to make everything seem normal". During the ceremony, some of my father-in-law's religious relatives found out that the rabbi was Conservative, so they left the wedding as an act of protest.

My parents -in-law did not tell us about that, we came to know about it because one of my brothers-in-law told us: "Yehuda and his family said they know that rabbi and then they stood up and went away without saying anything to anyone!". Needless to say that leaving a wedding ceremony is perceived as a shaming act that conveys reluctance to accept and acknowledge of the new marital bond.

In order to be eligible to receive a mortgage with an interest rate that is partly subsidized by the government as all "regular" couples are, we traveled to Antalya, Turkey five months later and had a civil marriage ceremony which is recognized by the Israeli Ministry of Interior since 1978 when Israel ratified theApostilleConvention. When we arrived at the marriage beaureu we hired a personal English-Turkish translator. She asked us why we arrived to get married in Turkey and was appalled that ancient religious marital prohibitions are still valid in contemporary democratic states such as Israel; the senior director of this marriage beaureu refused to register us as married for an hour and we had to explain to her why we had no choice but to marry by civil marriage out of our country. Like the translator, she was also astonished and said there are no similar marital prohibitions in her country. At last she agreed to marry us and we felt relieved after the long persuasion efforts that put us in much stress and embarrassment. We took some pictures from the short civil marriage ceremony and we keep them until today, however we still have not shown them to our children. Our children, a 18 year old girl and 17-year old twins (a boy and a girl) are still not aware that their parents were religiously forbidden to marry each other, and we still do not want to tell them.

When my husband called his friends to invite them to the wedding, a good friend told him: "Are you crazy? Your children will be mamzerim! Think again about your decision to marry her!!". Mamzerim (offspring of a married woman who conceived from extramarital sexual relations) are excluded from Israel's community for seven generations, hence embodying the most shameful status a person can have. There is an unwitting de-legitimating of CDCs by mistakenly attributing illicit status to their children. A few years ago, I studied the attitudes toward illicit children and discovered that most people-including Cohanim-regard children of CDCs as mamzerim (bustards) rather than chalalim (the plural form of chalal), albeit this is mistaken and inaccurate - and I believe this mistake leads people to see CDCs as deviants because of the purportedly problematic status of their offspring.

While my own parents, as atheists, were not bothered by the fact that my groom is a Cohen, the issue of our prohibited liaison seems to have been treated quite ambivalently by my husband's parents, most probably because they are religious. My father-in-law expressed a 
very lenient approach, saying: "If the divorcée has no children, she should be considered as never married", and hence eligible to marry a Cohen. He nevertheless told me that he did not disclose the fact that I was a divorcée when he told his siblings that his son was getting married; he continued to hide this information when he handed them invitations to our wedding. The major motif that concerned my mother-in-law, was, in her words: "We live in a religious environment, we go to the synagogue every Sabbath", so she was worried about "what they would think of us".

My mother-in-law said that in ancient times when the temples were the central location of religious performance, the Cohanim were entitled to receive many gifts from the people, and if she had seen her son losing all these benefits, she would have tried to convince him to cancel the wedding. As for my husband, he also said he would not have married me if there were still a Holy Temple in Jerusalem. There is an additional social aspect: my husband explained that the Holy Temple would bring back the old hierarchies, and he would have been excluded from his community if he had been married to a divorcée. None of my in-laws said we should tell our children that we are mutually proscribed from marrying each other, except for my mother-inlaw who in reply to my question suggested, that if one of our daughters would meet a Cohen around the age of 16-17, then in that case we should "explain the situation, which is not such a severe catastrophe!". A similar attitude was expressed by my husband, who prefers not to tell our son he may be considered a profaned Cohen: "I would not like to cause my boy any sorrow; I do not want him to feel different, that he is inferior to others".

As I wrote above, five months after our Conservative Jewish wedding ceremony, we were compelled to seek a civil marriage which is recognized by the State of Israel, in order to receive a subsidized mortgage and also to be accepted to live in a community village which accepts only officially married heterosexual couples, (undoubtedly - discrimination against all other types of potential residents! Two more violations of human rights). We chose the cheapest option at that time, which was to have a civil ceremony in Turkey. We arrived to Antalya, Turkey in the evening, rose early the next morning and went to the Marriage Bureau. Unfortunately, the manager and secretaries did not speak English, so we went to the streets in the center of the city and looked for someone who could help us translate our request to get married from English to Turkish. We felt helpless, and started losing hope that we would be able to get married in Antalya during the three days we had planned to stay there. We thought that all this trouble and expense were for nothing. However, it was probably one of the luckiest days of our lives as we met on the street professional English- to- Turkish translator who spoke excellent English! We were so excited and felt as if we had met an angel! We hired her services for that fateful day and drove back to the Marriage Bureau in a taxi. We explained to her that we wished to register as a married couple. Since most CDCs tend to go to Cyprus for this purpose, it was the first time that a CDC had arrived there and asked for marriage registration. The translator asked me: "Why don't you get married in Israel?" - and I answered: "We had a Temple some four thousand years ago and all of the men who belonged to the family named Cohen were considered sacred and hence forbidden to marry divorced women. My partner is a descendant of this sacred family. I am divorced and hence we are forbidden to get married in Israel". The translator wondered why this prohibition was still valid despite the fact that the Temple was destroyed two times and the Cohanim do not have any tasks to perform that are different or superior in any sense than those of any other Jewish man. I told her that many of the Jewish people still hope and yearn for a Third Temple to be rebuilt and therefore insist on preserving the marital prohibitions on Cohanim.

My husband and I have three children, and our concern has focused mainly on three realms: 1). At the time that our son was studying for his Bar-Mitzvah, we were preoccupied with the decision whether to tell the teacher who prepares Bar-Mitzvah boys for reading in the synagogue, that our son might be a chalal. We were not sure of our son's status, and also did not feel comfortable asking the rabbi whether our son would be honored by being the first to be called up to say the blessings before the Torah reading (the Cohanim are honored by being called up first), and whether he might perform the traditional Cohanim blessing (a bless ingrecited by Cohanim who have a special duty to bless the congregation in the name of God).About a year ago we went to the Bar-Mitzva of my brother-in-law's son and my son sat next to him during the prayers; there were some more cousins and family relatives who were not Cohanim so after the boy recited his blessing the rabbi asked for another Cohen to come upstage; My son wanted to recite the Cohanim blessing, however my father-in -law told him 
immediately: "Your turn well come later on, let David pray before you, he is older than you". In doing so my father-in-law managed to preserve the traditional supremacy ascribed to 'kosher' Cohanim and still did not disclose my son he is not a 'kosher' Cohen. 2). As each of our two daughters might be considered a chalala, we hoped they would not fall in love with a Cohen or alternatively, any Cohen they meet would agree to a civil marriage; 3). We were unanimous, from the very first days of our children's birth, that until our children reach puberty and consolidate their self-esteem and self-image, we should not tell them that our marriage was forbidden in our country and that their Halakhic status is problematic. We still do not want to tell them and try to postpone "the conversation" as much as possible. I assume I will tell them when they reach their early 20's. My oldest daughter insists she will not get married by religious marriage ceremony, without knowing anything about her being a chalala. If she gets to fall in love with a Cohen, they will anyway be forbidden to get religiously married so the "problem" will persist to future generations.

Both of us and my husband more so, usually feel hesitant and embarrassed to tell religious and traditional people that we are a Cohen - divorcée couple. If the subject of the conversation in a social meeting touches issues such as how we met for the first time, etc., my husband tries to avoid telling people about it. If he hears me talking about it, he sometimes tries to change the topic of conversation. There have been some occasions that I told people during social gatherings that we were forbidden to marry each other and my husband felt embarrassed and asked me later: "Why did you HAVE to tell them? What for?". Usually there is no special response by those who hear our story, except for an Orthodox marital counselor with whom we consulted about a decade ago, asking for help in finding a solution to a controversial issue unrelated to our forbidden marriage. I told her during the second session that we are a CDC and she proceeded with the session as usual. The day after the session she called my husband and apologized that she could not continue to meet us because we are a CDC. My husband told her: "Please consult with your rabbi and ask for his permission!" and she said: "It appears that my rabbi is your uncle, your father's cousin. He forbade me to perform marital counseling for any CDC. I am really sorry: I cannot act against my personal values". I vividly remember myself, some ten years after it happened, standing next to my husband and listening to this conversation on the speaker of his cellular phone; and I could do nothing but burst into bitter and frustrated tears.

We felt flawed. We felt like strangers, outsiders, aliens in our own homeland! My husband told me angrily: "Why did you tell the counselor we are a CDC? Why did you HAVE to tell her? Couldn't you remain silent?!!!" And I answered him: "You cannot hide it; it would come out somehow in any case, sometime later in other sessions". I did not regret what I had disclosed to her that we are a CDC, because I believe that if providing marital counselling for CDCs is in contrast to her religious beliefs, I would not like to cause someone to unwittingly act in a way that contradicts her belief system. I thought for years about this awful though understandable rejection by the marital counselor, and I came to realize that it was so painful for both of us, because she was very professional and we had had high expectations from her to help us improve our marital communication. Since that rejection which occurred about 10 years ago, we were so traumatized that we never turned again to any marital counselor although we had conjugal controversies.

About a year ago, my husband was injured and had a serious rupture in his finger so we went to a specialist in surgery. The specialist was an Ultra-Orthodox man, and at the end of the consultation, he requested that my husband bless him by reciting the traditional Cohanim blessing; my husband agreed right away and felt embarrassed to disclose he cannot do it because he was a profaned Cohen and nevertheless preferred to bless him, despite the fact that such a blessing is not valid if recited by anyone who is not a "kosher" Cohen including a profaned Cohen. Although I tend to talk about the subject more easily and freely than my husband, I nevertheless can recall a few cases where I chose not to disclose our being CDC during social conversations. One of these few cases in which I felt SHAME occurred when I talked with the President and the Dean of the university at which I worked a few years ago, and the topic of CDCs was somehow mentioned. The President was laughing about CDCs with my Dean, saying something like - "how can they DARE to get married to each other?" - and I remained silent and did not mention that I myself was involved in such a liaison. I did not want to embarrass the President, but I also worried about creating a bad impression on them, that could impact my academic career. A similar yet different scenario occurred in our home, when 
we hosted for the first time a religious couple that we met a few days earlier. They told us how they met each other and then I told them how we met each other; I hesitated whether to mention that we are a CDC, eventually I decided to tell them, and it was our first and last meeting, because since that time they avoided meeting us again.

Like all other couples, my husband and I have controversies and quarrels from time to time. As all other couples, our disagreements focus on the "usual" issues of budget priorities as well as attitudes toward our children's education. And as all other couples, we sometimes consult with our parents about potential solutions to our disagreements. In contrast to all other couples, since the first days of our conjugal life, I tend to experience bad feelings whenever I have a fight with my husband; I imagine myself "seeing" and "hearing" my in-laws telling my husband "we told you not to marry her! If she is divorced there must be a reason; it is surely something with her problematic personality...It must have been her fault that her marriage failed", and so on. There are so many wicked things that would or could never be said about a never married daughter-in-law.Yet, all these unjust claims have been said, or I just thought they have been said, understandably make me so sad and offended.

\section{Concluding thoughts}

The greater significance accorded to maintaining the equilibrium of the social structure of Israel is at the expense of womens' ability to fulfill their human rights. This reality is therefore highly instrumental, providing empirical evidence for Eekelaar's (2017) concept of "the era of Instrumentalism"; referring to the personal law system he claims: "...as designed primarily to maintain a particular social structure, rather than to respond to the interests, or well-being, of individuals.... [family law] justifications primarily based upon an appeal to maintaining identified social structures, rather than an appeal to the well-being of individuals. Since individual well-being was subsumed into the maintenance of social structures, I call this the era of Instrumentalism" (2017, p. 9).

The instrumentalist stance is manifested also in cases where religious laws of a certain religion are applied to individuals who do not subscribe to the religion, but that are ascribed to them by the state, based on their genealogy; such cases are seen as "...unfair, intolerant, disrespectful, and invasive of autonomy..." (Ahmed, 2016, p. 143). Due to the exclusive jurisdiction of religious courts over marriage and divorce and the subsequent compulsory application of religious law to these matters, many citizens are subject to infringementsof their religious freedom (Scolnicov, 2006). Paradoxically, human rights are not realized because of Sezgin's (2013) ironic observation: "...pluri-legal personal status systems are thereby inherently incompatible with international human rights law" (2013, p. 62). Unfortunately, as this project demonstrates, this infringement permeates the most intimate aspects of a person's life, namely their romantic choices and relationships throughout their lifetimes, and sometimes also impact all future generations of offspring, as in the case of chalal. The religious autonomy of prospective male descendants of CDC is limited, because if one or more of them wishes to become religiously observant and benefit from the venerated position of a Cohen in a religious community they may choose to live in, it will not be possible.

In general, linking the personal and the political aspects of human rights violations is the core mission of social scientists and practitioners (Ife, 2001); in particular, as a female social scientist, I enlisted myself to address women's marital rights. By the same token, the increasing globalization trend is raising new challenges to international social policy-making in the area of family affairs (Gray \&Fook, 2004). Therefore, social scientists should strive to assist not only individuals and communities in need; rather, they may wish to contribute their input to policy making at national levels (Ife, 2001). We should always bear in mind that the voices of silenced women should receive the highest priority to be heard; therefore, if Israel aims to provide social justice to all citizens, men and women equally, as other human rights programs over the world (Ife, 2001), there is much work to do in order to establish a just and egalitarian society. The current situation is far from being just, and the existent practiceshave the potential to decrease respect for women's human rights.

I maintain that the liminal status of CDCs undermines the power of the millet system and has the potential to impoverish its dominance and its tacit exclusionary power. If the State of Israel opted to preserve the Milletsystem as a means to increase the homogenization among Jews, as suggested by Sezgin (2013), then liminal CDCs, both at the individual and couple unit of analysis, intensifythe fractured nature of the "fragmented confessional" model of the personal 
status system, in an unexpected way: that of de-homogenizing the dominant Jewish sector splitting them into those who observe Jewish religious marital laws and those who resist them. CDCs cross symbolic red lines, a transgression which might pave the way to what is perceived by most Jews as a worse consequence, namely, intermarriage between Jews and non-Jews.

Since the state cannot prevent CDCs from cohabiting or marrying through civil marriage, it gradually loses its power, while competing societal institutions such as the Reform and Conservative Jewish religious movements. This process supplements extant scholarship regarding the impact of the power balance between the state and additional actorsimpacting the state's ability to dominate family issues (Sezgin, 2013; Eekelaar, 2017). However, here we witness a reverse directionality - where the power balance is impacted by the privilege of the state to intervene in women's private family matters.A broader conclusion relates to the infringement of human rights; Although both spouses are mutually proscribed from marrying each other, the prevalent notion is that the Cohen marries a divorced woman downwardly, that is hypogamy for him, while the woman marries upwardly, i.e. hypergamy for her; marriage is a sort of regimenting institute so CDCs manage to avoid religious regimentation by the state, something that may threaten the stability and moral boundaries of the Jewish society in the state of Israel. The case of the CDCs demonstrates how religion can oppress women via marital rules and perpetuate women's weakness and inferiority. Therefore, I propose that women's marital liberty should be accorded the highest respect, instead of being abused as a tool for power struggles between state and religionin the pseudo-democratic State of Israel.

The issue of granting marital liberty to women who are religiously forbidden to marry their beloved male partners illustrates a specific type of inherent paradox explored by An-Na'im (2013). He argues that there are inevitable paradoxes of universality and self-regulation followed by the state that are inherent to the application of human rights to every cultural, religious and ideological context. An-Na'im (2013) defines the "paradox of universality"as referring to the worldwide expectation of global agreement on universal human right norms among peoples belonging to diverse and radically different cultural and religious traditions around the globe. An-Na'imalso refers to self-regulation by the state as a paradox, as each state is expected to implement universal human right norms that actually limit its own powersde facto. The paradox of universality is equally valid and relevant to the expectation that the State of Israel would be violating the delicate homeostasis of state-religion relations by forgoing divorced women's marital prohibitions.

Inspired by Nussbaum (2000), I raise the question: Are the Cohanim marital prohibition not to marry divorced women- which seem to be cruel and unjust in many cases - really central in contemporary Judaism? Do these prohibitions stem from pure religious piety? Obviously the answer is NO to both questions. Undoubtedly there are political forces within the Israeli state that act to preserve these prohibitions in an era in which a Third Temple will not be rebuilt? I believe that the Israeli government does not have a drive nor a specific interest to reform the existent personal law. I therefore call to extend Article 23 to include an additional important clause focusing on the negative right for women of being free from marital prohibitions; hopefully, this important clause would entail the cancelling of Cohanim and divorcées marital prohibition. I also invite the leadership of the Jewish personal law courts to design a plan for a reform which would accord the full ratification of ICCPR by Israel. Each state that has joined an international treaty in general, and the ICCPR in particular, should strictly abide by this treaty and should be cognizant that control mechanisms may be used to ensure the fulfillment in practice of the guidelines delineated by the ICCPR.

What can be done, if at all, if states fail to provide their citizens marital liberty? Nakamura and Yamamoto (2009) are straightforward, and assert that "the contemporary system of global governance proved incapable of constraining the action of the powerful U.S., which highlights the complex and often conflicting relationship between global governance and unilateralism in the international society. At the same time the global governance system proved unable to facilitate adherence to the international law regime by the members of the international society."(2009, p.148). International shaming has been suggested to overcome this fallacy, in a strategy known as "naming and shaming" (Hafner-Burton, 2008; Kahn-Nisser, 2018). According to this strategy, "governments, non governmental organizations (NGOs), and the news media often 'name and shame' perpetrators of human rights abuses" (Hafner-Burton, 2008, p. 689). A study examining the effectiveness of such international condemnation found that in democracies and hybrid regimes - those combining democratic principles with 
authoritarian elements (like in the Israeli case)- opposition parties and relatively free presses paradoxically make leaders less likely to actto adopt laws and norms that respect human rights vis-a-vis international criticism (Hendrix \&Wong, 2012). The quest to enforce respect for human rights has yielded an elaborate strategy which combines both negative critique and shaming with the provision of incentives for implementing human right practices (Kahn-Nisser 2018). This is a unique model for the effective enforcement of respect for human rights, by combining shaming in international mass communication with financial incentives. The financial incentives are provided by the coercing body, either by attaching economic benefits to policy change, or by imposing economic sanctions on states that fail to comply with rules of human rights. It has been found that neither shaming nor financial incentives/coercion can independently facilitate the change of existent policies and practices in the states that violate certain human rights; the combination of these two complementary strategies has been proven to have an effective impact on countries in improving their human right policies and laws (Kahn-Nisser, 2018).

Contemplating today my auto-ethnographic project, I arrived to the understanding that thanks to this project - on which I embarked five years ago, I began to undergo a gradual process quite quickly after its beginning, a process wherein I stopped being embarrassed about telling of my forbidden marriage. I presented a part of my work in a University seminar and in a research group which focused on mixed families. The positive feedback I received from the audience and from colleagues who heard about my project contributed to my selfempowerment and enhanced my devotion to the mission to which I enlisted myself, namely, cancelling arbitrary marital prohibitions. The final thing I still refrain from doing is telling our three children of the prohibition, and I still keep it as a "family secret", everybody in our familial and social network knows about our being mutually prohibited from marrying each other except for our children. I refrain from talking about my auto-ethnographic project in their presence, and they are not aware of it. My husband and I intend to explain it to them when they reach puberty. I hope the present project will trigger contemplation regarding the needed reconsideration of the missing clause to be added to Article 23, and in so doing, will diminish human sorrow and predicament, by securing every man and woman the appropriate human right for marital liberty.

\section{Funding statement}

This work received no funding from any source.

\section{Conflict of Interest}

The author declares there are no conflicts of interest to declare.

\section{Notes on Contributor}

Dr. Ya'arit Bokek-Cohen received her Ph.D. in Sociology at Tel-Aviv University in 2002 and her post-doctorate in University of Montreal in 2017. Bokek-Cohen specializes in Sociology of the family; her research focuses on families and reproductive technologies, mate preferences, family dynamics, spousal influence strategies, marital power balance, and matchmaking. Her current research project focuses on the limited marital liberty of individuals in democratic states. She recently published several articles in Journal of Social Work \& Human Rights; International Journal on Minority and Group Rights; Journal of Gender Studies; American Journal of Bioethics; Women's Studies International Forum, Journal of Family Studies. 


\section{References}

Abu-Rabia-Queder, S. (2007). "Coping with 'Forbidden Love' and Loveless Marriage among Educated Bedouin Women from the Negev." Ethnography, 8(3), 297-323.

Ahmed, F. (2016). Religious Freedom under the Personal Law System. Oxford: Oxford University Press.

Ahuja, A., \& Osterman, S. L. (2016). Crossing Caste Boundaries in the Modern Indian Marriage Market. Studies in Comparative International Development, 51(3), 365-387.

Anderson, L. (2006). Analytic Auto ethnography. Journal of Contemporary Ethnography,35(4), 373-395.

Anxious Observer.(1869). Marriage with a Deceased Wife's Sister Forbidden by the Word of God: Containing Also the Refutation of a Passage in the Speech of Lord Kimberley, Delivered in the House of Lords on This Subject in March, 1859. Bristol Selected Pamphlets.

Chatterejee, N. (2010). English Law, Brahmo Marriage, and the Problem of Religious Difference: Civil Marriage Laws in Britain and India. Comparative Studies in Society and History, 52(3), 524-552.

Clarke, M. (2007). The Modernity of Milk Kinship. Social Anthropology, 15(3): 287-304.

Douki, S., Ben Zineb, S., Nacef, F., \& Halbreich, U. (2007). Women's mental health in the Muslim world: Cultural, religious, and social issues. Journal of Affective Disorders, 102(1-3), 177-189.

Eekelaar, J. M. (2011). Naturalism or Pragmatism? Towards an Expansive View of Human Rights. Journal of Human Rights, 10(2), 230-242.

Eekelaar, J. M.(2017).Family Law and Personal Life. (2nd ed.), Oxford: Oxford University Press.

Ellis, C., \& Bochner, A. (2000). Autoethnography, Personal Narrative, Reflexivity: Researcher asSubject. In Handbook of Qualitative Research, edited by N. K. Denzin and Y. S. Lincoln,(2nded.), Thousand Oaks, CA: Sage, pp.733-768.

Ermakoff, I. (1997). Prelates and Princes. American Sociological Review,62, 405-422.

Fogiel-Bijaoui,S. (2002).Familism, Post modernity and the State: The Case of Israel. Journal of Israeli History: Politics, Society, Culture, 21(1-2): 38-62.

Fogiel-Bijaoui, S. (2003). Why Won't There Be Civil Marriage Any Time Soon in Israel? Or:Personal Law- the Silenced Issue of Israeli-Palestinian Conflict. Nashim: A Journal of Jewish Women's Studies and Gender, 6, 28-34.

Fogiel-Bijaoui, S. (2013).The Spousal Covenant (Brit Hazugiut), or the Covenant with the Status Quo. Israel Studies Review, 28(2), 210-227.

Fogiel-Bijaoui, S. (2017). Transmitting the Nation: Family Individualization and Religion In Israel. In Gender, Families and Transmission in Contemporary Jewish Context, edited by S. Nizard, M. Gross, \& Y. ScioldoZürcher, Newcastle-upon-Tyne, UK: Cambridge Scholars Publishing, pp. 90-101.

Frías, S.M. (2017). Family and Partner Violence against Women: Forced Marriage in Mexican Indigenous Communities. International Journal of Law, Policy and the Family, 31, 60-78.

Furth, R.(2005). Marrying the Forbidden Other: Marriage, Status and Social Change in Futa Jallon Highlands of Guinea. Doctoral dissertation submitted to University of Wisconsin-Madison.

Galanter, M., \& Krishman, J. (2000).Personal Law and Human Rights in India and Israel. Israel Law Review, 34, 101-133.

Gray, M., \& Fook, J. (2004). The Quest for a Universal Social Work: Some Issues and Implications. Social Work Education, 23(5), 625-644.

Ife, J. (2001). Local and Global Practice: Relocating Social Work as a Human Rights Profession in the New Global Order. European Journal of Social Work, 4(1), 5-15.

Ife, J. (2012). Human Rights and Social Work: Towards Rights-Based Practice. Cambridge: Cambridge University Press.

International Covenant on Civil and Political Rights (ICCPR).( 2018), Retrieved from: http://www.ohchr.org /Documents/Publications/FactSheet2Rev.1en.pdf

Kapila,K.(2004). Conjugating Marriage: State Legislation and GaddiKinship. Indian sociology,38(3): 379-409. 
Koensler, A. (2018). Affective Borderlands: Experiences in Practice of the Neo-Zionist Settling Enterprise in the Israeli Periphery. Journal of Contemporary Ethnography.

Merin, Y.(2005). The Right to Family Life and Civil Marriage under International Law and its Implementation in the state of Israel. Boston College International and Comparative LawReview, 28(1): 79-147.

Nussbaum, M. C. (2000). Women and Human development: The capabilities approach. Cambridge: Cambridge University Press.

Ottenheimer, M. (1996). Forbidden Relatives: The American Myth of Cousin Marriage. Illinois: University of Illinois Press.

Peled-Shapira,H. (2013). 'Permitted and Forbidden' - Conventions of Relations between the Sexes and Their Contravention as Reflected in the Novels ofGhā'ibṬ úma Farmān. Middle Eastern Studies, 49(3): 402-413.

Rehman, J. (2007). The Sharia, Islamic Family Laws and International Human Rights Law: Examining the Theory and Practice of Polygamy and Talaq. International Journal of Law, Policy and the Family, 21, 108-127.

Scolnicov, A. (2006). Religious Law, Religious Courts and Human Rights Within Israeli Constitutional Structure. International Journal of Constitutional Law, 4(4), 732-740.

Sezgin,Y. (2013). Human Rights under State-Enforced Religious Family Laws in Israel, Egypt and India. Cambridge: Cambridge University Press.

Van Wichelen, S. (2009). Polygamy talk and the politics of feminism: Contestations over masculinity in a new Muslim Indonesia. Journal of International Women's Studies, 11(1), 173-188. 